This item was submitted to Loughborough's Research Repository by the author.

Items in Figshare are protected by copyright, with all rights reserved, unless otherwise indicated.

\title{
SMEs and regional economic growth in Brazil
}

PLEASE CITE THE PUBLISHED VERSION

PUBLISHER

(c) Loughborough University

VERSION

VoR (Version of Record)

LICENCE

CC BY-NC-ND 4.0

REPOSITORY RECORD

Cravo, Tulio A., Adrian R. Gourlay, and Bettina Becker. 2019. "Smes and Regional Economic Growth in Brazil". figshare. https://hdl.handle.net/2134/6005. 
This item was submitted to Loughborough's Institutional Repository (https://dspace.lboro.ac.uk/) by the author and is made available under the following Creative Commons Licence conditions.

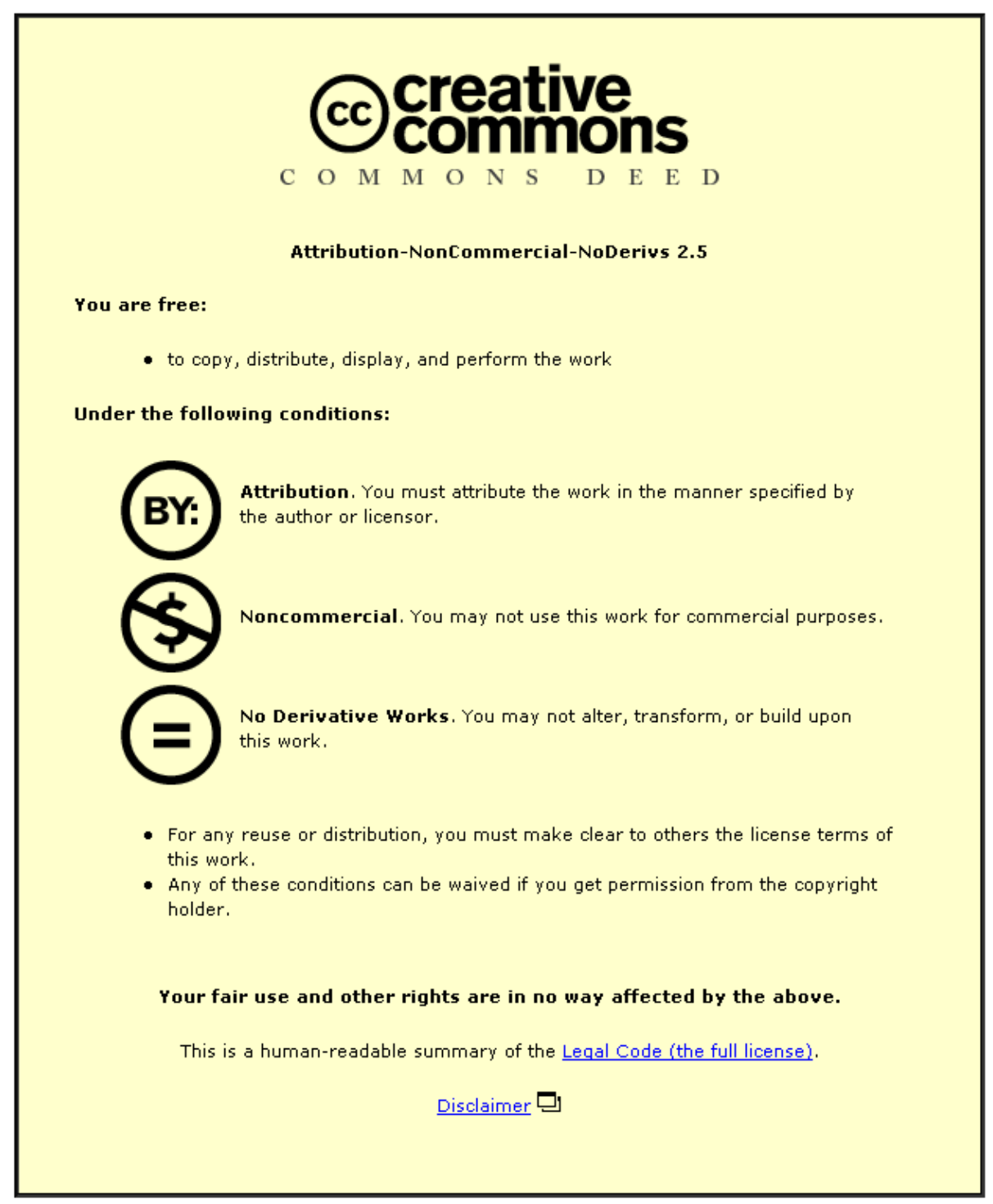

For the full text of this licence, please go to: http://creativecommons.org/licenses/by-nc-nd/2.5/ 
ISSN 1750-4171

\title{
DEPARTMENT OF ECONOMICS
}

\section{DISCUSSION PAPER SERIES}

SMEs and Regional Economic Growth in Brazil

\author{
Túlio A. Cravo \\ Adrian Gourlay \\ Bettina Becker
}

WP 2010 - 01

Dept Economics

Loughborough University

Loughborough

LE11 3TU United Kingdom

는 Loughborough

Tel: + 44 (0) 1509222701

Fax: + 44 (0) 1509223910

http://www.lboro.ac.uk/departments/ec 


\title{
SMEs and Regional Economic Growth in Brazil
}

\author{
Túlio A. Cravo ${ }^{\dagger *} \quad$ Adrian Gourlay ${ }^{\dagger}$ \\ Bettina Becker ${ }^{\dagger}$ \\ ${ }^{\dagger}$ Department of Economics, Loughborough University
}

December 18, 2009

\begin{abstract}
This paper examines the relationship between the Small and Medium Enterprise (SME) sector and economic growth for an annual panel of Brazilian states for the period 1985-2004. We investigate the importance of the relative size of the SME sector measured by the share of the SME employment in total formal employment and the level of human capital in SMEs measured by the average years of schooling of SME employees. The empirical results indicate that the relative importance of SMEs is negatively correlated with economic growth, a result that is consistent with previous studies examining developing countries. In addition, our results also show that human capital embodied in SMEs may be more important for economic growth than the relative size of the SME sector.
\end{abstract}

Keywords: Firm size, market structure, economic growth, human capital. JEL Classification: O1, O15, L11.

*Corresponding author: T. A. Cravo, Department of Economics, Loughborough University, Leicestershire, LE11 3TU, United Kingdom. e-mail: t.antonio-cravo@lboro.ac.uk 


\section{Introduction}

In recent years interest in the linkages between small and medium sized enterprises (SMEs) and economic growth has been attracting increasing attention. However, there is a paucity of studies examining the importance of SMEs for economic growth in developing countries. This is surprising given that the SME sector is the target of international and national aid agencies. Indeed, in 2003 the World Bank approved US\$1.3 billion in SME support programs (Beck et al. 2005).

Studies that have examined the impact of SMEs on economic growth include the seminal study by Beck et al. 2005 who estimate an amended standard growth regression that includes the relative size of SME sector for a cross-section of countries. A similar approach is also employed in Audretsch and Keilback (2004) and Muller (2007) to evaluate the impact of entrepreneurship on economic growth in developed countries. Whilst studies that focus on a cross-section of countries suggest a negative or neutral impact of SMEs and entrepreneurship on economic growth, those studies examining developed countries suggest a positive impact. Summarising the results of empirical studies, Van Stel et al. (2005) and Wennekers et al. (2005) provide evidence that suggests a positive impact of entrepreneurship on growth for developed countries and the converse result for developing countries. Acs et al. (2008) has attributed these differences in empirical results to different entrepreneurship responses to institutional arrangements. Moreover, heterogeneity in institutional arrangements and human capital levels across countries and regions are likely to provide different incentives to rent-seeking activities (see, for example, Dias and McDermott 2006; Baumol 1990).

A limitation of the empirical literature to date is the relatively little attention devoted

to study SMEs and entrepreneurship in the developing countries relative to developed countries. The aim of this paper is to address this gap in the literature by providing an analysis of the importance of SMEs for regional economic growth in Brazil for an annual panel of states from 1985 to 2004. Brazil provides an interesting case study because the Brazilian SME support service (SEBRAE) provided US\$ 1.1 billion financial support for 
SMEs in 2007 and the SME sector employs the majority of the labour force in Brazil ${ }^{1}$. This paper makes a number of contributions to the literature. Firstly, this paper draws on Beck et al. (2005) and uses growth regressions to encompass the importance of the relative size of the SME sector into the growth analysis. Secondly, it provides an extended analysis of the relationship between SME and growth by focusing on the stock of SMEs' human capital, measured by a newly constructed variable for the average years of schooling in SMEs. The relative employment size of the SME sector alone might not be informative about its interaction with growth and so the inclusion of the level of SMEs' human capital can add another dimension of SME activity to the analysis. The remainder of the paper is as follows. Section 2 discusses the importance of SMEs as a determinant to economic growth. Section 3 presents the growth framework and the model specification. Section 4 presents the data and methods of estimation. Section 5 presents and discusses the results and Section 6 concludes.

\section{SMEs as Determinants to Economic Growth}

Audretsch and Keilbach (2004) and Audretsch (2007) have argued that entrepreneurship and small firms are an important determinant of economic growth, but note that they have been omitted in the neoclassical growth framework. Moreover, Solow (2007) recognises entrepreneurship as an important activity that drives a wedge between knowledge and total factor productivity by bridging the gap between specific pieces of technological knowledge and innovations through the creation of new firms. Therefore, explaining how SMEs impact on growth can add to the explanatory power of traditional growth theory.

According to Beck et al. (2005), the pro-SME policy view as embraced by the World Bank, for example, is based on the argument that the SME sector brings social benefits that stem from greater competition and are therefore (potentially) more productive than large firms. However, financial markets and other institutional failures impede the development and growth of SME activity. The argument that institutional arrangements

\footnotetext{
${ }^{1}$ In 2005, SMEs accounted for approximately $52.5 \%$ of the Brazilian labour force(Relação Anual de Informações Sociais). See Table 1 for further details.
} 
are important for entrepreneurship and growth is put forward in Baumol (1990). Baumol argues that while the total supply of entrepreneurs differs across economies, the productive contribution of the society's entrepreneurial activities varies much more due to their allocation between productive and unproductive activities. Therefore, policy makers should be concerned about the allocation of entrepreneurship by providing an institutional arrangement that promotes productive entrepreneurship at the expense of rent seeking ${ }^{2}$. Similarly, Baumol (2008) argues that institutions are important to entice entrepreneurs away from their previous unproductive activities and lead them into innovative productive undertakings.

Institutions are also important to stimulate human capital formation for productive entrepreneurs. Dias and McDermott (2006) develop a model where structural changes towards a modern economy depend on the role of entrepreneurs, human capital and institutions. In this setting, entrepreneurs come from a pool of individuals that belong to the managerial class, which is specialised in two activities: rent-seeking and entrepreneurship. Importantly, more (productive) entrepreneurs lead to more human capital formation. Workers will seek education in order to find a more productive job (i.e. that requires a higher level of human capital) offered by the entrepreneurs. Therefore, a policy response is to remove barriers that prevent productive entrepreneurship to develop and better institutions are required to create more productive entrepreneurs and entice human capital formation. If unproductive entrepreneurship dominates, educational improvement will be neutralized and will have little long-run effect.

The importance of institutions for entrepreneurship is assessed by Nystrom (2008) for a panel of 23 OECD countries over the period 1972-2002. Nystrom uses self-employment as a proxy for entrepreneurship and includes measures of economic freedom (size of the government, legal structure, access for money, freedom to trade and regulation of credit) to account for the institutional quality in the growth regressions. Nystrom's results support the argument that institutional quality is important for the entrepreneurial activity. Therefore, if institutions fail, it is likely the performance of SMEs will also fail. Further-

\footnotetext{
${ }^{2}$ According to Baumol (1990), unproductive entrepreneurship takes many forms such as litigation and takeovers, tax evasion and avoidance efforts.
} 
more, Beck et al. (2005) argue that institutional failure in the form of financial constraints prevents SMEs to fully develop and can be a burden to their capacity of generating economic growth. Similarly, Michelacci and Silva (2007) provide evidence that financial markets are a constraint to local entrepreneurship.

In the context of developed countries, Audretsch and Thurik (2001) argue that an 'entrepreneurial economy' based on small firms has emerged as a result of the telecommunication, microprocessor revolution, and of the advent of low-cost but highly skilled competition (mainly) in Eastern Europe and Asia. As a result the comparative advantage of high-wage economies is no longer compatible with routine economic activity. Maintenance of high wages requires a knowledge-based economic activity that cannot be costlessly diffused across geographic space and the shift towards small firms is fundamental in this process. In developed countries, SMEs could be a sign of a dynamic economy that sustains economic growth based on new technologies. For example, Audretsch and Keilbach (2004) and Muller (2007) measure entrepreneurship using start-up rates and find a positive effect of entrepreneurship capital on growth in Germany.

Nevertheless, due to differences in institutions, human capital and rent-seeking levels, the presence of SMEs in a developing economy probably does not have the same implications as it has in a knowledge-based economy ${ }^{3}$. In a cross-country analysis, Van Stel et al. (2005) found a negative effect of entrepreneurship on growth for developing countries and the opposite result to developed ones. As entrepreneurship seems to have a different impact on economic performance according to the level of economic and institutional development (Acs et al. 2008), the presence of SMEs alone is problematic to interpret. Differences in the level of economic and institutional development provide diverse incentives to productive entrepreneurship and consequently we do not know whether the effect of SMEs on growth comes from the structure itself or from another factor related to SMEs, such as the level of human capital.

Importantly, the size of the SME sector does not take into account the level of SMEs'

\footnotetext{
${ }^{3}$ For example, Table 1 in Beck et al. (2005) shows that SMEs' employment share in Brazil is 58.8\% while in Finland is $58.15 \%$. However, the effect of SMEs on growth is very likely to be different due to different characteristics of SME sector. Therefore, a proxy for the presence of SMEs does reflect the true impact of SMEs on growth.
} 
human capital. In Nelson and Phelps (1966), the rate of increase in technology level is an increasing function of educational attainment; education speeds up the adoption and diffusion on product and process innovations. Similarly, Barro (2001) argues that human capital facilitates the absorption of superior technologies and generates growth. Complementary, human capital can also encourage growth by stimulating the process of innovation. Griffith et al. (2004) argue that R\&D has two faces and stimulates growth directly through innovation and indirectly through facilitating the imitation process. They found evidence that educational attainment have an important role in stimulating both, the absorption of superior technologies (absorptive capacity) and innovation. We apply these arguments to the SME sector and argue that the absorptive capacity of the SME sector is an important factor to be considered when studying the relationship between SMEs and growth.

Therefore, a SME proxy that encompasses human capital can shed additional light on the relationship between SMEs and growth once it can encompass the ability of the SME to appropriate knowledge from more productive firms. If the SME sector improves its productivity, through innovation or imitation, a positive effect on growth is expected from the SMEs' human capital level.

\section{The Model Specification}

Models by Solow (1956) and Mankiw et al. (1992) provide a theoretical framework for growth regressions. However, the most common approach to empirically modelling economic growth is an ad hoc regression that encompasses other factors that influence growth (Temple, 1999). In this approach, variables are selected based on previous results in the literature rather than on an explicit theoretical model. Regressions of this type are known as 'Barro Regressions', after Barro's (1991) seminal work. Therefore, the hypothesis of convergence has been tested by estimating the following simple equation:

$$
g r_{i t}=a_{i}+b \ln y_{i, t-1}+\psi X_{i t}+v_{i t}
$$

where $i$ denotes each individual economy, $t$ denotes time, $g r$ denotes the GDP per 
capita growth, ln $y_{t-1}$ is the initial GDP per capita, $b$ the convergence coefficient and $X$ is a vector of variables that control differences across economies. This $X$ vector encompasses the growth determinants suggested by the original Solow model as well as other growth determinants that come from outside the model. If the convergence coefficient is negative $(b<0)$ and $\psi \neq 0$, then the data is said to exhibit conditional convergence.

Following the influential work of Mankiw et al. (1992) and Barro (1991), the growth literature based on equation (1) flourished and considered hundreds of policy and structural variables into the growth framework. Levine and Renelt (1992) and Durlauf et al. (2005) have listed an extensive number of variables that were used in growth regressions. In this context, Sala-i-Martin (2001) argues that an important contribution made by the growth literature that follows this tradition is that it has exerted influence on other research areas of economics such as development, economic geography, macroeconomics, econometrics and industrial organisation. Recently, this influence was also extended to importance of SMEs and entrepreneurship for economic growth (e.g. Beck et al 2005; Audretsch and Keiback 2004; Muller 2007). Consequently, the specification used in this paper to study SMEs and growth in Brazilian states takes the following form:

$$
g r_{i t}=a_{i}+b \ln y_{i, t-1}+\beta \ln S M E R_{i t}+\alpha \ln S M E H_{i t}+\psi \ln X_{i t}+v_{i t}
$$

where the notation is identical to that used in equation (1), but importantly the regression equation includes measures of SMEs activity: SMER is the relative size of the SME sector and $S M E H$ is the human capital of SME sector, respectively. The variables in vector $X$ encompass growth determinants suggested by Mankiw et al. (1992): the overall level of human capital, physical capital and the population growth ${ }^{4}$.

\section{Data and Methods of Estimation}

To analyse economic growth and SMEs in Brazil, a data set combining Brazilian states with the aggregate results of individual establishment data to account for the SMEs

\footnotetext{
${ }^{4}$ Adjusted for depreciation $(\delta)$ and technological growth $(\mathrm{g})$, under the usual assumption that $\delta+\mathrm{g}$ equals 0.05 .
} 
measures at state level was constructed. What follows is a brief description of the variables and their sources.

Real GDP per capita for each state (GDPpc) was collected from IPEADATA (Instituto de Pesquisa Econômica Aplicada Database). We were able to collect annual data for the period 1985-2004 ${ }^{5}$. However, to control for business cycles we did not use the annual data directly, but the 3-year average over the sample period ${ }^{6}$. All series were also averaged over a 3-year period. The data for population used to calculate the population growth $(n)$, and the average years of schooling of the population over 25 years old (School), were also taken from IPEADATA. A limitation in our data is the absence of data on physical capital for Brazilian States. As a proxy, the average of industrial consumption of electricity $(K)$ for each 3-year period from IPEA is used. This measure has been extensively used as a proxy to capital stock in Brazil (e.g. Lau et al 1994; Ferreira 2000; Nakabashi and Salvato 2007). Lau et al. (1994), for example, argue that this measure has the advantage over the capital stock since it already embodies a rate of utilization adjustment.

RAIS (Relação Anual de Informações Sociais) provided the information necessary to construct our SMEs' measures. RAIS is a comprehensive administrative census dataset collected annually by the Brazilian Ministry of Labour. It covers the formal sector of the economy with demographic information for workers and establishments that can be retrieved according to size criteria in terms of employment ${ }^{7}$. The relative size of the SME sector $(S M E R)$ is measured by the share of the SME sector in the total formal labour force in manufacturing. We used 250 employees as a cut-off point to define SMEs; this definition

\footnotetext{
${ }^{5}$ A longer time series is not available due to a change in the national accounts' methodology from 2004 onwards.

${ }^{6}$ Using the annual data allows more degrees of freedom for the relative short panel time length of our study. However, to control for business cycles we used a 3-year average to reduce its influence. This approach still allows the use of five cross sections in the GMM-DIFF estimates, since two cross-sections are lost to control for the lagged GDPpc and to take the first difference. Increasing the time length to the usual 5-year average would reduce the degrees of freedom and we do not have the minimum of three cross sections necessary to calculate the diagnostic tests for the GMM estimates (see Arellano and Bond 1991).

${ }^{7}$ In 2004, RAIS covers 31.5 million workers. If an establishment fails to report the information required by RAIS, employers will face fines that are proportional to their workforce size. However, because the payment of the annual wage supplement is based on RAIS, employers and workers have strong incentive to fulfil RAIS records. The software SGT micro, provided under request from the Ministry of Labour was used to retrieve the information necessary to construct our SMEs' measures.
} 
follows Beck et al. $(2005)^{8}$. In addition, we were able to construct this measure extending the definition of the SME sector, incorporating commerce and services (SMER2). Finally, we constructed the new variable for the average years of schooling in SMEs $(S M E H)$ manufacturing from the information relating to educational attainment retrieved from RAIS. We follow Muendler (2007) and attribute a number of years of schooling to each level of educational attainment provided by RAIS to generate a continuous series ${ }^{9}$. Our new variable for human capital in SMEs is constructed as follows:

$$
S M E H=\frac{\sum_{i=0}^{N}\left(E^{i} \times S^{i}\right)}{E}
$$

where $E_{i}$ is the number of SME employees in each range of education, $S_{i}$ the number of years of schooling for that particular range and $E$ is the total number of SME employees. We also constructed this variable incorporating commerce and services sectors (SMEH2).

Our data concerning SMEs are not without caveats. As observed by Beck et al. (2005), SME measures are static and do not account for the entry of new firms, graduation of successful SMEs into large and the exit of failing ones. In addition, RAIS returns are completed on a self-classification basis and as a result establishments might classify themselves incorrectly. However, we believe that most of these problems are offset by the census nature of RAIS and by its size and extensive coverage. In terms of measurement, according to the Ministry of Labour, omissions of information are frequent in small municipalities and in the agricultural, construction and public administration ${ }^{10}$.

Therefore, our final data set is a balanced panel data from 1985 to 2004 for 25 Brazilian States $^{11}$ averaged over a 3-year period to control for business cycle influences. A panel data approach is used to estimate equation (2). First, we estimate the model assuming state fixed effects using the Least Square Dummy Variable (LSDV) estimator. As an

\footnotetext{
${ }^{8}$ We also used 100 employees as cut-off point to define SMEs and found similar results.

${ }^{9}$ See appendix for further details.

${ }^{10}$ The omission of information in small municipalities is not likely to affect the quality of data at state level. In addition, agriculture, construction and public administration information are not used to construct our SMEs measures.

${ }^{11}$ Brazil is divided into 27 Federal Units including the Federal District of Brasília. The most recent State (Tocantins) was created in 1988 which constitutes the northern territory of the former state of Goiás. These two states were excluded from the sample.
} 
alternative, the GMM in first difference (Arellano and Bond 1991) and the system GMM (Blundell and Bond, 1998) are used to take into account the endogeneity problem that emerge in growth regressions.

\section{Empirical Results}

\subsection{Growth and the SME sector size}

The existing literature provides evidence of convergence for Brazilian states and suggests that convergence is conditioned to structural factors such as population growth, physical capital and human capital (e.g. Lau et al. 1993; Ferreira 2000; Azzoni 2001; Nakabashi and Salvato 2007). Our approach complements these previous studies by providing results incorporating the SME sector into the growth framework.

Table 1 illustrates the potential disparities that can drive convergence among Brazilian states along with the size of the SME sector for each state.

\section{[Insert Table 1 here]}

The data in Table 1 shows that income, population, physical and human capital are concentrated in southern states. These asymmetries are also reflected in the heterogeneity of employment shares of SMEs across states. States in the south east and south regions have a similar structure with approximately 60 percent of the formal employment in manufacturing generated by SMEs. Figures for the SMEs' employment share vary more for poorer states, from 13 percent in Alagoas to 100 percent in Roraima. These inter-state differences require a more careful analysis of the role of the SME sector when controlling for other growth determinants.

Regression results obtained from estimating equation (2) are presented in Table 2. From columns 1 to 5, the estimations include only SMER to account for the SME sector, as in Beck et al (2005), and we do not control for the industrial electricity consumption. 
Column 1 reports the results for the LSDV and indicates a strong convergence pattern, a positive effect of education on growth, and a negative but not significant effect stemming from population growth. These results are consistent with the existing empirical literature on Brazil. For the SME sector, we observe a negative and significant effect of SMER on growth, indicating that SMEs are negatively associated with economic growth. However, the LSDV model does not address endogeneity, and to take this into account, the GMM in first difference (GMM-DIFF) and the system GMM (GMM-SYS) are alternative estimators to tackle this potential problem.

Results for the one-step and two-step GMM-DIFF and GMM-SYS estimates are reported from columns 2 to 5 respectively. The results for both estimators confirm the existence of conditional convergence and the positive impact of education on growth with a high degree of significance. Again, the coefficients on the population growth indicate no statistical significance. The coefficients for the size of the SME sector in manufacturing is always negative and is significant for both one-step estimations, consistent with the initial evidence found by the LSDV estimator, and therefore supporting the view that SMEs are negatively related to economic growth in Brazil. In addition, diagnostic tests for the validity of instruments presented at the bottom of the table do not indicate any problem with the validity of the internal instruments. The values for $m_{2}$ are the $p$-values for the autocorrelation test under the null of no autocorrelation and values for Hansen test are the $p$-values for the joint validity of the instruments under the null that the instruments are valid.

The inclusion of the industrial electricity usage, as represented in columns 6 to 10 , does not change the results. The presence of SMEs in manufacturing is robust to the inclusion of this variable, increasing our confidence about the sign of this effect.

[Insert Table 2 here]

Therefore, even after controlling for endogeneity, our results support the argument that SMEs are not important for growth. This result is consistent with, for example, Van 
Stel et al. (2005) who find a negative effect of entrepreneurship on growth for developing economies.

Thus far, our analysis is based only on the manufacturing sector and this was also a shortcoming identified by Beck et al. (2005) that argue that it would be useful to have information on SME employment beyond manufacturing. Consequently, we extend the work of Beck et al. (2005) by including SME employment share in manufacturing, commerce and services (SMER2). Table 3 mimics the structure of Table 2 and reports the same estimations for our extended SME sector.

\section{[Insert Table 3 here]}

Overall, we observe that extending the SME sector to incorporate commerce and service sectors provides the same qualitative analysis, although the results for the GMMDIFF estimates are less clear-cut with respect to the initial finding of a negative impact of SMER on growth. The initial analysis represented in Table 2 still holds in Table 3: the coefficients on the initial GDP per capita are strongly significant, the positive effect of education on growth is confirmed and the coefficients on the population growth remain without statistic significance most of the times ${ }^{12}$. When we consider the effect of the SME extended sector on growth, the analysis also supports the view that SMEs do not promote growth, a finding strongly supported in the GMM-SYS estimates. The coefficient of SME sector is found to be always negative and significant at conventional significance levels. Estimates controlling for physical capital provide similar results.

Therefore, our empirical results indicates that the extended SME sector does not present a different dynamics and is not positively associated with economic growth. The absence of a positive effect of the SME sector size on growth can be explained by institutional failures that prevent SMEs' development and productive entrepreneurship to thrive, as discussed in Section 2.

\footnotetext{
${ }^{12}$ Similar insignificant results for population growth were found by Nakabashi and Salvato (2007). This result could be related to the fact that income per capita is the main determinant of migration in Brazil. This significant population growth endogeneity makes its coefficient insignificant.
} 


\subsection{SMEs' Human Capital and Economic Growth}

The finding that a larger SME sector does not lead to higher economic growth could also be explained by the role of human capital. SMEs may have relatively lower levels of human capital and therefore are not able to contribute to productivity growth, an explanation hinted by Van Stel et al. (2005). However, Van Stel et al. (2005) did not have a proxy for the entrepreneurs' human capital and were unable to test this hypothesis. The inclusion of SME human capital $(S M E H)$ is a distinctive contribution of our empirical analysis. We expect a priori that higher levels of human capital in SMEs are associated with higher levels of productivity in SMEs because the presence of higher skilled workers facilitates the adoption of a new technology used elsewhere (absorptive capacity) through a process of technological diffusion described by Nelson and Phelps (1966). Moreover, Griffith et al. (2004), argue that human capital can also constitute an important aspect of the innovation process (innovative capacity) that leads to productivity improvements and growth. Hence, the relative size of the SME sector alone might not be informative about its interaction with growth and the level of SMEs' human capital would add information to the analysis. Consequently, drawing on the suggestion by Van Stel et al. (2005), and to extend the analysis of Beck et al. (2005), we include the proxy for SMEs' human capital, SMEH, in our growth regressions.

The results for the extended specification with $S M E H$ are shown in Table 4. Columns 1 to 5 present results without physical capital. The inclusion of $S M E H$ does not change the initial analysis drawn from the results in the previous section. The estimates shown in Table 4 present similar results for the conditioning variables, an indication that the causal relationship initially found is robust to the inclusion of this new aspect of the SME sector. For example, SMER is again negatively related to growth. Results with the addition of the variable $S M E H$ indicate that higher levels of SME's human capital does not reduce economic growth and in fact has a positive and significant coefficient in the one-step GMM-DIFF estimation (column 2), supporting the view that this characteristic of the SME sector could be an important growth determinant. The inclusion of the physical capital proxy again provide very similar results, the main difference is that the significant 
effect from $S M E H$ disappears and becomes insignificant. However, importantly there is weak indication that this aspect of SMEs is important for economic growth in Brazil.

\section{[Insert Table 4 here]}

To complement the analysis, results with the inclusion of SME's human capital for the extended SME sector, including services and commerce, are provided in Table 5. Again, the extension of this sector provides similar results. The estimates from columns 1 to 5 show that SMER2 is always negatively related to growth and is significant for the GMM-SYS estimations. The variable SMEH2 is always positive and is significant for the one-step GMM-DIFF estimates, as in Table 4, providing additional support to the idea that the quality of SMEs might be more important than its presence. For the full model with the inclusion of physical capital (from columns 6 to 10), results are, again, very similar. As in Table 4, the main difference is that the significant effect from $S M E H$ disappears.

[Insert Table 5 here]

Therefore, there is indication of a weakly positive relationship between growth and $S M E H$. However, this relationship is not robust to the inclusion of a proxy for physical capital. This weak positive effect on growth can be related with the fact that institutions do not provide the stock of productive entrepreneurs necessary to induce and activate the human capital made available for SMEs. Better institutions also create the condition that incites more human capital formation that will be better used by productive entrepreneurs (Dias and McDermott, 2006). This effective use of human capital means that SMEs can actually use it to increase productivity making use of its potential absorptive capacity (Nelson and Phelps, 1966) and its innovative capacity (Griffith et al., 2004). 


\section{Conclusion}

This paper has provided the first systematic investigation into the importance of the employment share and level of SME human capital for regional economic growth in Brazil. The empirical results indicate that the size of the SME sector has a negative effect on regional growth and SMEs' human capital has an weakly positive effect on growth.

The finding that the size of the SME sector is not positively associated with growth does not mean that small businesses should be discouraged in Brazil. Instead, our results could be interpreted as a sign that some factors do not entice the right type of small firms. Institutional failure is one factor that can encourage rent seeking activities that would be reflected in a negative association between growth and SME activity. Similarly, the weakly effect of SMEs human capital on growth can be reinforced with institutional improvement. More productive entrepreneurs would provide an impetus for more human capital formation and who will make full use of the skills available in the small firms.

Therefore, our results do not support the view that SMEs should be supported directly

to promote economic growth. Consequently, the size of the SME sector should not be increased per se to promote growth. Rather, institutional improvement and educational policies should be the focus to of policy makers by enabling more human capital formation for a more productive SME sector.

\section{Acknowledgement}

We would like to thank the Brazilian Ministry of Labour for providing access to RAIS database.

\section{Appendix}

[Insert Table 6 here] 


\section{References}

[1] Acs, Z., Desai, S., Hessels, J., (2008). Entrepreneurship, economic development and institutions. Small Business Economics, 31(3), 219-234.

[2] Arellano, M., Bond, S., (1991). Some tests of specification for panel data: Monte Carlo evidence and an application to employment equations. Review of Economic Studies, 58(2), 277-297.

[3] Audretsch, D.B., (2007). Entrepreneurship capital and economic growth. Oxford Review of Economic Policy, 23(1), 63-78.

[4] Audretsch, D., Keilbach, M., (2004). Entrepreneurship capital and economic performance. Regional Studies, 38(8), 949-959.

[5] Audretsch, D., Thurik., R., (2001). What's new about the new economy? Sources of growth in the managed and entrepreneurial economics. Industrial and Corporate Change, 10(1), 267-315.

[6] Azzoni, C.R., (2001). Economic growth and regional income inequality in Brazil. Annals of Regional Science, 35(1), 133-152.

[7] Barro, R., (1991). Economic growth in a cross section of countries. Quarterly Journal of Economics, 106(2), 407-43.

[8] Barro, R., (2001). Human capital: growth, history, and policy - A session to honor Stanley Engerman. Human Capital and Growth. American Economic Review, 91(2), $12-17$.

[9] Baumol, W.J., (1990). Entrepreneurship - Productive, unproductive, and destructive, Journal of Political Economy, 98(5), 893-921.

[10] Baumol, W., (2008). Small enterprises, large firms, productivity growth and wages. Journal of Policy Modeling, 30(4), 575-589.

[11] Beck, T., Demirguc-Kunt, A., Levine, R., (2005). SMEs, growth, and poverty: Crosscountry evidence. Journal of Economic Growth, 10(3), 199-229.

[12] Beck, T., Demirguc-Kunt, A., Laeven,L., Levine, R., (2008). Finance, firm size and growth. Journal of Money, Credit, and Banking, 40(7), 1379-1405.

[13] Blundell, R., Bond, S., (1998). Initial conditions and moment restrictions in dynamic panel data models. Journal of Econometrics, 87(1), 111-143.

[14] Dias, J., McDermott, J., (2006). Institutions, education, and development: The role of entrepreneurs. Journal of Development Economics, 80(2), 299-328.

[15] Durlauf, S., Johnson, P., \& Temple, J. (2005). Growth econometrics. In P. Aghion., S. Durlauf(Eds), Handbook of economic growth, Chapter 8: Elservier. 
[16] Ferreira, A., (2000). Convergence in Brazil: Recent trends and long-run prospects. Applied Economics, 32(4), 479-489.

[17] Griffith, R., Redding, S., Van Reenen, J., (2004). Mapping the two faces of R\&D: Productivity growth in a panel of OECD industries. The Review of Economics and Statistics, 86,(4), 883-895.

[18] Lau, L.J., Jamison, D.T., Lius, S., Rivkin, S., (1993). Education and economic growth: Some cross-sectional evidence from Brazil. Journal of Development Economics, 41(1), 45-70.

[19] Levine, R., Renelt, D., (1992). A sensitivity analysis of cross-country growth regressions. American Economic Review, 82(4), 942-963.

[20] Mankiw, G., Romer, D., Weil, D., (1992). A contribution to the empirics of economic growth. Quarterly Journal of Economics, 107(2), 404-437.

[21] Michelacci, C., Silva, O., (2007). Why so many local entrepreneurs? Review of Economics and Statistics, 89(4), 615-633.

[22] Mueller, P., (2007). Exploiting entrepreneurial opportunities: The impact of entrepreneurship on growth. Small Business Economics, 28(4), 355-362.

[23] Muendler, M., (2007). Trade and workforce changeover in Brazil. National Bureau of Economic Research (NBER), Working Papers $n^{\circ} 12980$.

[24] Nakabashi, L., Salvato, M., (2007). Human capital quality in the Brazilian states. Revista ANPEC, 8(2), 211-229.

[25] Nelson, R., E. Phelps., (1966). Investment in humans, technological diffusion, and economic growth. American Economic Review 56(1/2), 65-75.

[26] Nystrom, K., (2008). The institutions of economic freedom and entrepreneurship: evidence from panel data, Public Choice, 136(3-4), 269-282.

[27] Roodman, D., (2009). How to do xtabond2: An introduction to difference and system GMM in Stata, Stata Journal, 9(1), 86-136.

[28] Sala-i-Martin, X., (2002). 15 Years of New Growth Economics: What Have We Learnt? Universitat Pompeu Fabra Economics and Business Working Paper No. 620

[29] Solow, R., (1956). A contribution to the theory of economic growth. Quarterly Journal of Economics, 70(1), 65-94.

[30] Solow, R., (2007). The last 50 years in growth theory and the Next 10. Oxford Review of Economic Policy, 23(1), 3-14. 
[31] Temple, J., (1999). The new growth evidence. Journal of Economic Literature, 37(1), $112-156$.

[32] Van Stel, A., Caree, M., Thurik, R., (2005). The effect of entrepreneurial activity on national economic growth. Small Business Economics, 24(3), 311-321.

[33] Wennekers, S., Van Stel, A., Thurik, R., Reynolds, P., (2005). Nascent entrepreneurship and the level of economic development. Small Business Economics, 30(3), $325-325$. 
Table 1. Brazilian states and SME sector size

\begin{tabular}{|c|c|c|c|c|c|c|c|}
\hline State & Region & GDPpc & Population & Electricity $(\mathrm{K})$ & School & SMER & SMER2 \\
\hline Rio de Janeiro & $\mathrm{SE}$ & 9.94 & 15.20 & 6532659 & 7.63 & 60.97 & 69.94 \\
\hline São Paulo & $\mathrm{SE}$ & 9.32 & 39.83 & 45733046 & 7.44 & 58.67 & 68.26 \\
\hline Minas Gerais & $\mathrm{SE}$ & 5.96 & 18.99 & 23418872 & 6.11 & 64.72 & 74.17 \\
\hline Espírito Santo & $\mathrm{SE}$ & 6.99 & 3.35 & 3802839 & 6.56 & 74.38 & 78.01 \\
\hline Rio Grande do Sul & $\mathrm{SO}$ & 9.05 & 10.73 & 8846389 & 6.83 & 59.6 & 71.92 \\
\hline Santa Catarina & $\mathrm{SO}$ & 8.26 & 5.77 & 6969104 & 6.88 & 59.71 & 73.02 \\
\hline Paraná & $\mathrm{SO}$ & 7.28 & 10.14 & 8671576 & 6.68 & 63.23 & 74.43 \\
\hline Distrito Federal & $\mathrm{CW}$ & 12.95 & 2.28 & 357692 & 8.75 & 75.72 & 64.57 \\
\hline Mato Grosso & $\mathrm{CW}$ & 6.9 & 2.75 & 1134821 & 6.13 & 71.47 & 83.33 \\
\hline Mato Grosso do Sul & $\mathrm{CW}$ & 6.08 & 2.23 & 750304 & 6.19 & 55.58 & 77.24 \\
\hline Goiás & $\mathrm{CW}$ & 5.09 & 5.51 & 2746932 & 6.2 & 67.67 & 74.88 \\
\hline Amazonas & NO & 7.77 & 3.15 & 1315420 & 6.67 & 36.74 & 58.33 \\
\hline Amapá & $\mathrm{NO}$ & 4.62 & 0.55 & 23234 & 6.77 & 100 & 85.32 \\
\hline Rondônia & $\mathrm{NO}$ & 4.24 & 1.56 & 220927 & 5.56 & 88.63 & 89.94 \\
\hline Acre & NO & 3.49 & 0.62 & 24099 & 5.18 & 90.42 & 91.43 \\
\hline Roraima & $\mathrm{NO}$ & 3.32 & 0.38 & 13574 & 6.25 & 100 & 90.43 \\
\hline Pará & $\mathrm{NO}$ & 3.39 & 6.85 & 9773527 & 5.52 & 69.21 & 72.86 \\
\hline Tocantins & $\mathrm{NO}$ & 2.56 & 1.26 & 111022 & 5.35 & 86.21 & 9235 \\
\hline Sergipe & $\mathrm{NE}$ & 4.61 & 1.93 & 1132744 & 5.76 & 59.65 & 75.24 \\
\hline Bahia & $\mathrm{NE}$ & 4.31 & 13.69 & 9370866 & 4.86 & 61.74 & 72.78 \\
\hline Pernambuco & $\mathrm{NE}$ & 3.89 & 8.32 & 2227202 & 5.42 & 48.29 & 68.33 \\
\hline Rio Grande do Norte & $\mathrm{NE}$ & 3.65 & 2.96 & 1019962 & 5.21 & 52.6 & 73.48 \\
\hline Ceará & $\mathrm{NE}$ & 2.83 & 7.98 & 1862185 & 4.94 & 48.51 & 66.26 \\
\hline Paraíba & $\mathrm{NE}$ & 2.83 & 3.57 & 1019872 & 4.78 & 54.13 & 77.91 \\
\hline Alagoas & $\mathrm{NE}$ & 2.63 & 2.98 & 1841966 & 4.18 & 13.19 & 50.71 \\
\hline Piauí & $\mathrm{NE}$ & 1.96 & 2.98 & 181965 & 4.37 & 78.49 & 80.57 \\
\hline Maranhão & $\mathrm{NE}$ & 1.87 & 6.02 & 6633420 & 4.59 & 79.25 & 79.53 \\
\hline Brazil & & 6.61 & 181.59 & 145736225 & 6.40 & 52.20 & 71.07 \\
\hline
\end{tabular}

Notes: All variables in this table are defined in Section 4. Figures are from the most recent year of the panel. GDPpc is expressed in $\mathrm{R} \$(2000)$. Population figures are in millions of inhabitants. Industrial Electricity usage is expressed in MWh. School is the average number of years of schooling. SMER and SMER2 are the percentage of the employment in SMEs. The abbreviations SE, SO, CW, NO and NE stand for the Brazilian census regions of South-East, South, Centre-West, North and North-East, respectively. 


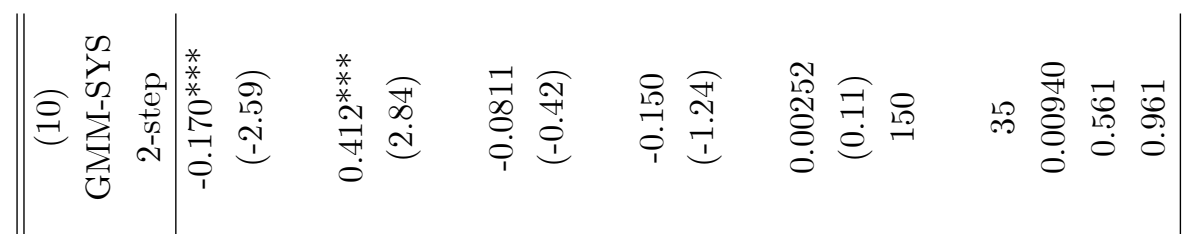

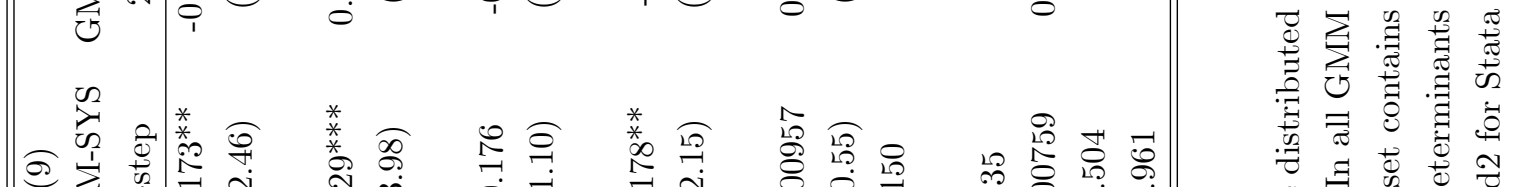

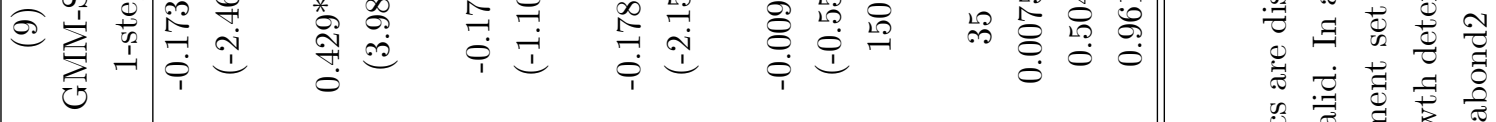

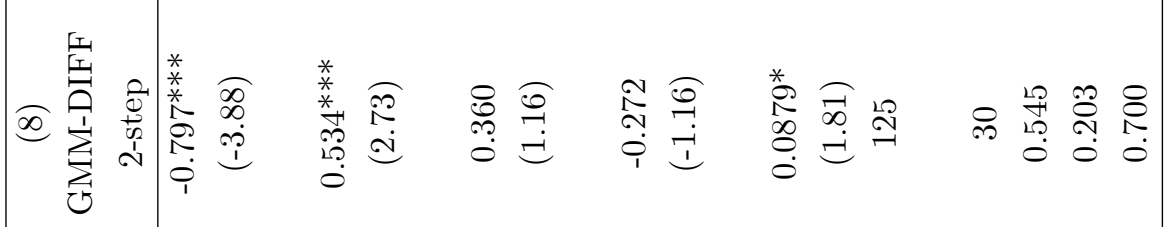

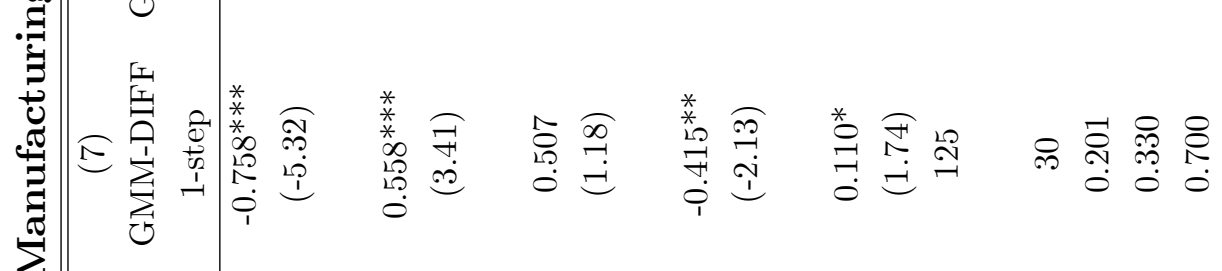

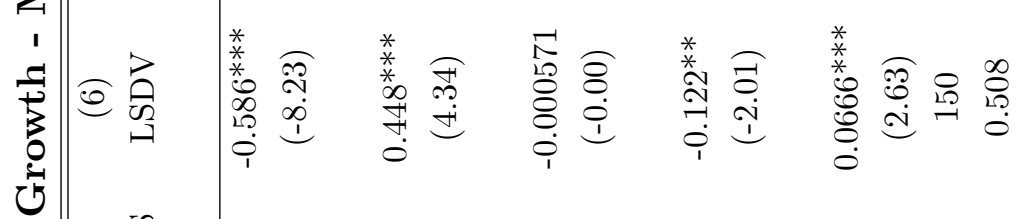

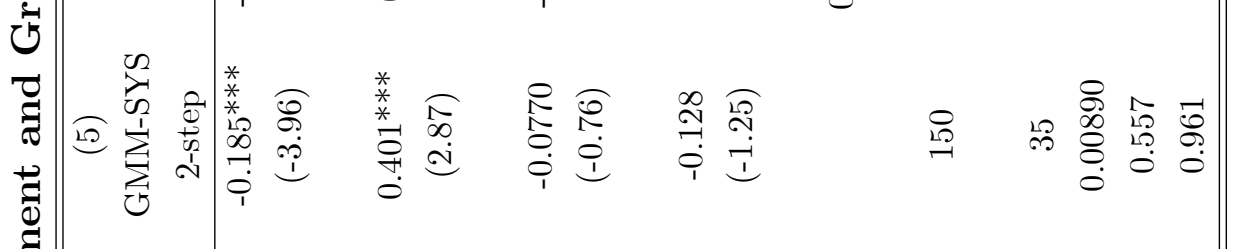

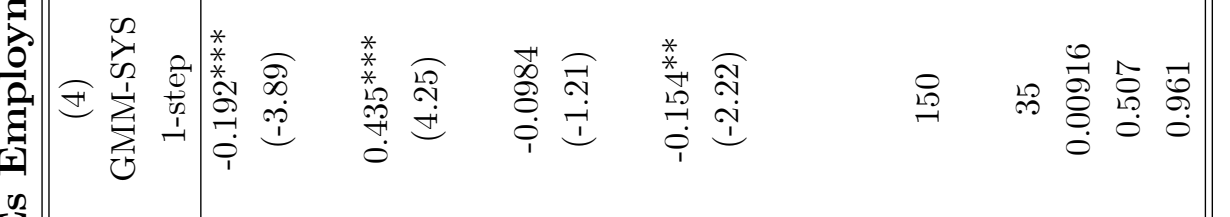

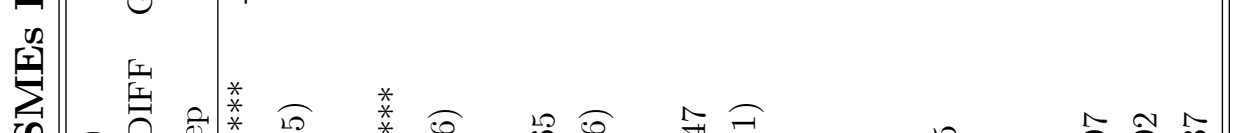

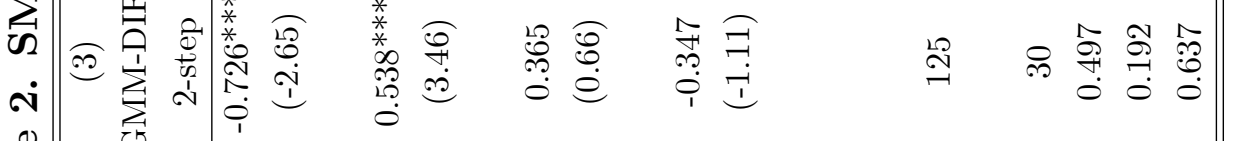
$\frac{0}{\frac{0}{6}}$

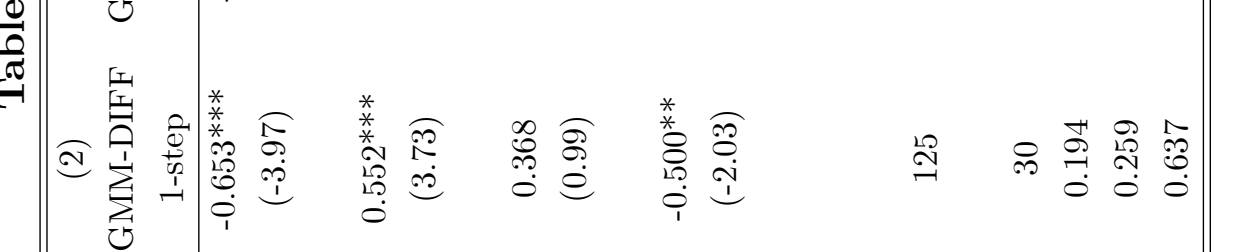

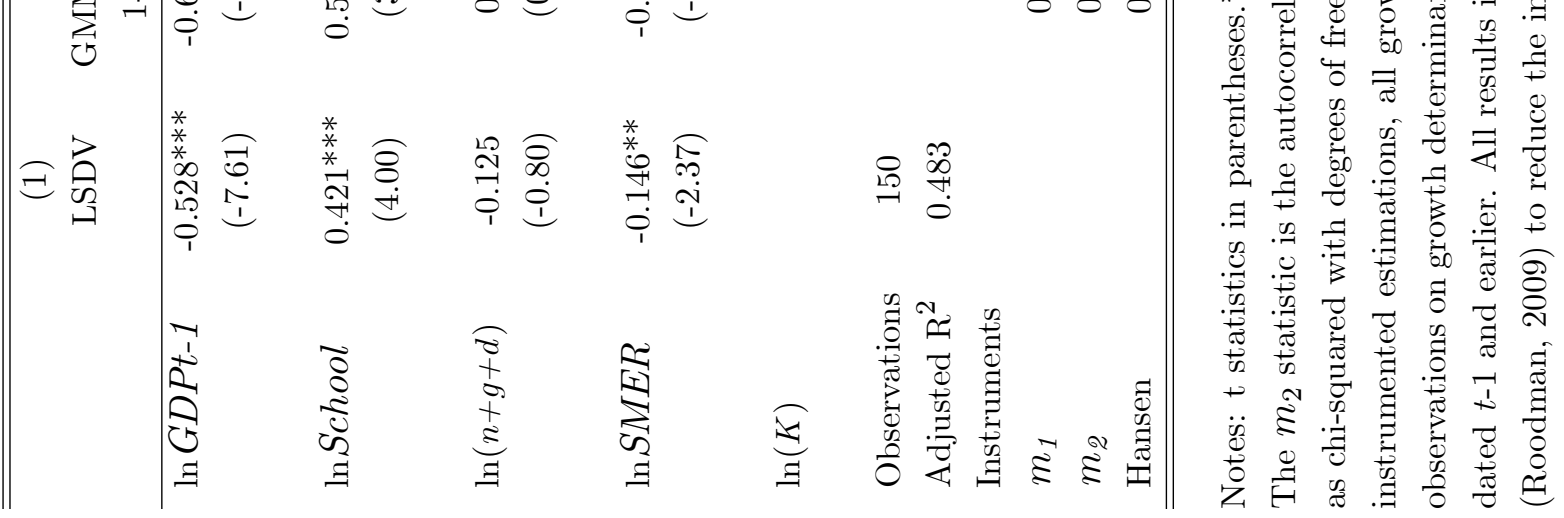




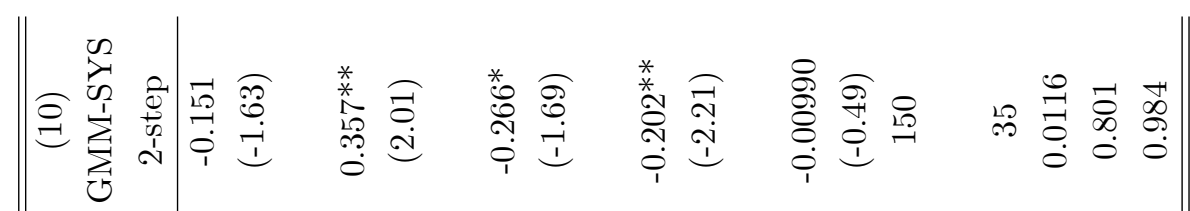

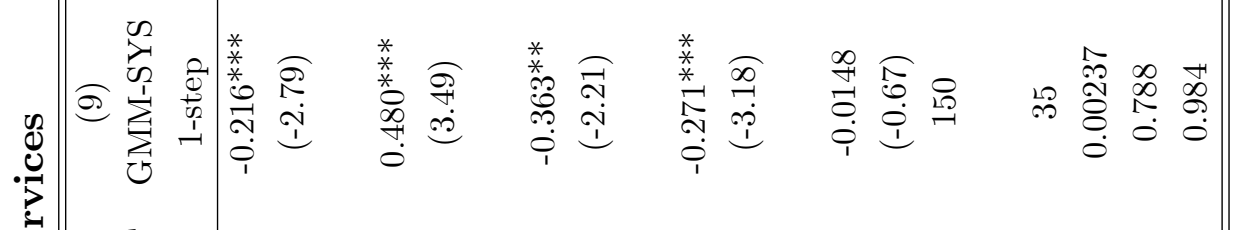

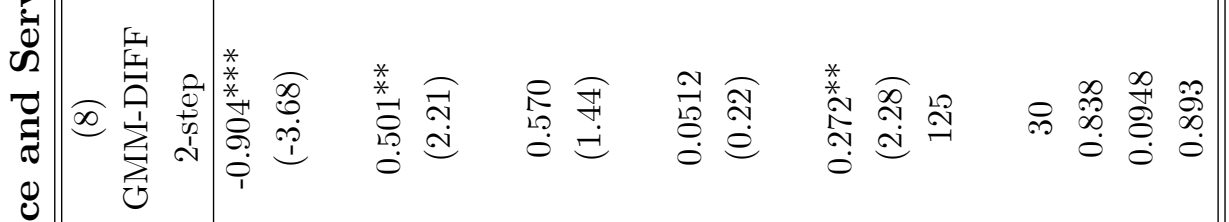

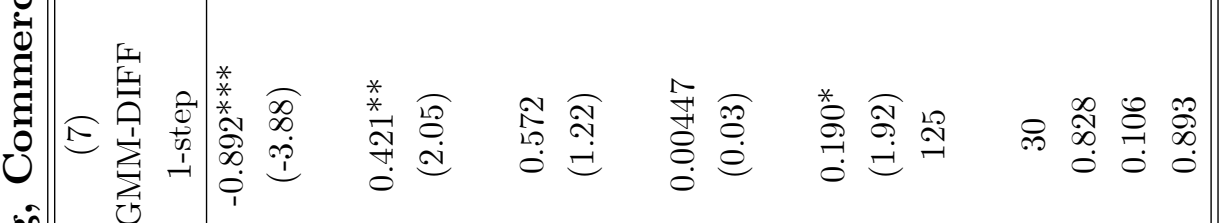

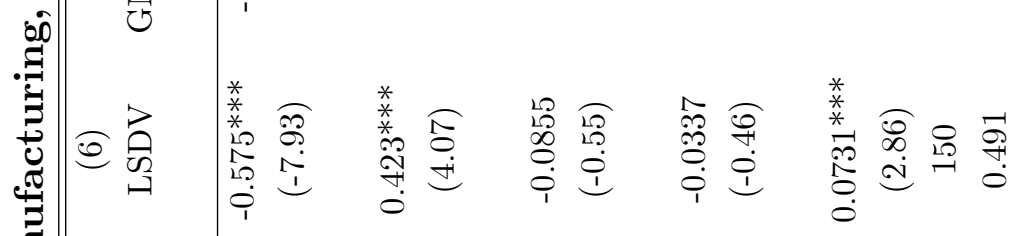

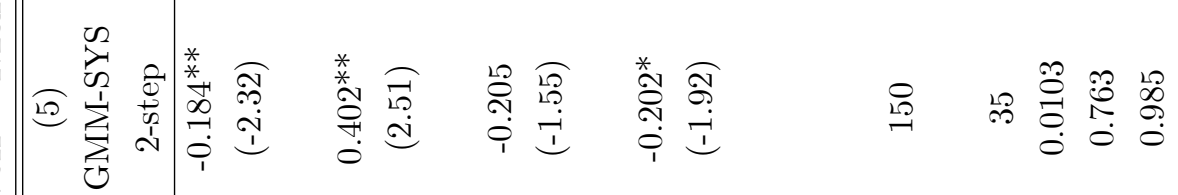

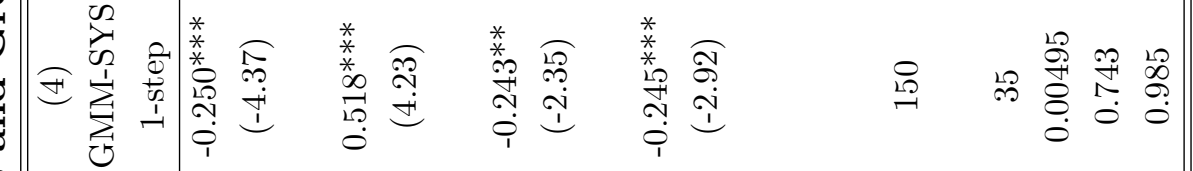

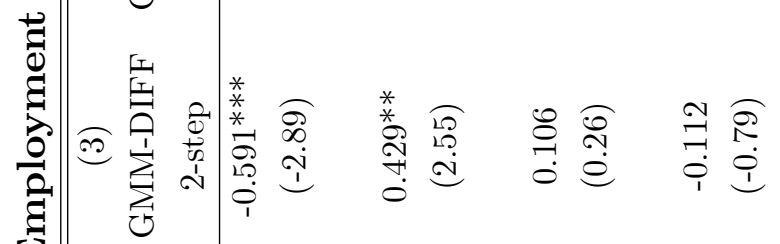

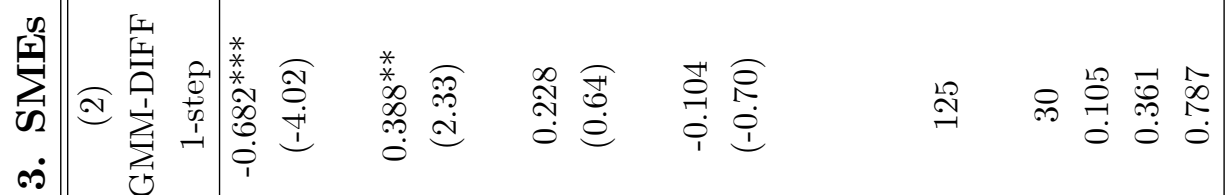

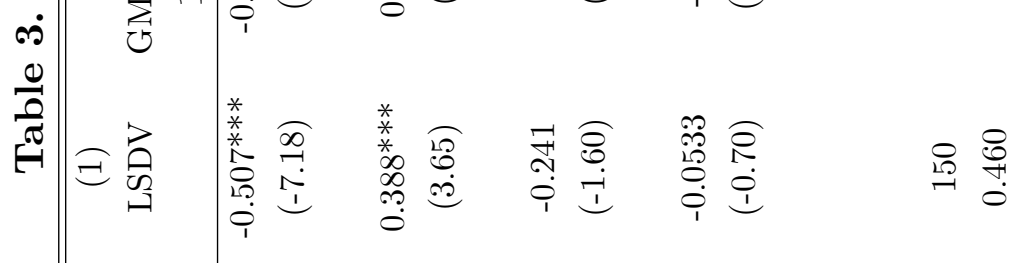

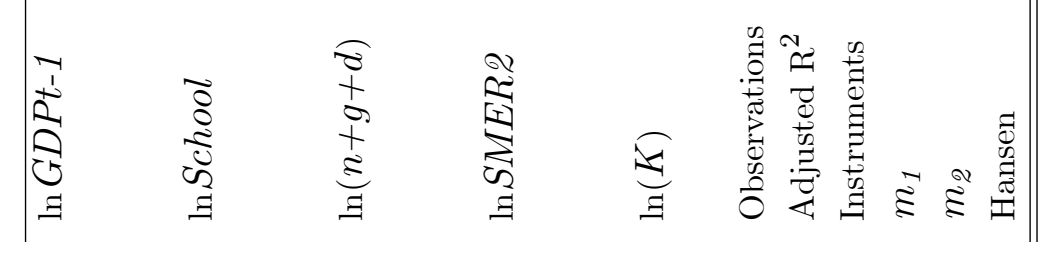

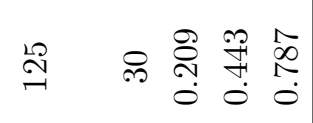

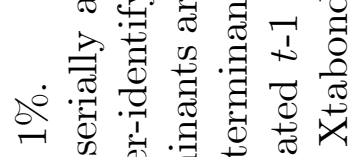
क क

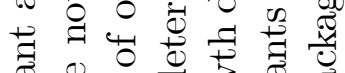
芯茪 क्ञ

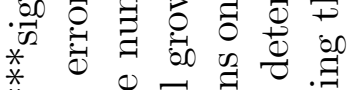

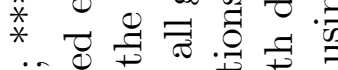
这皆 ๘ 可

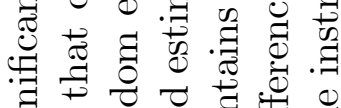

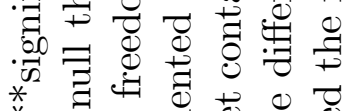

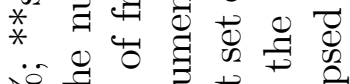

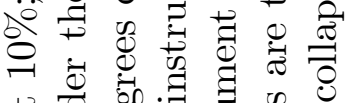

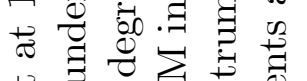

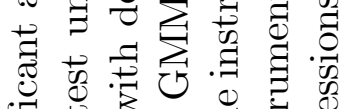
क्ञ

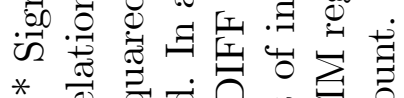
*. 记

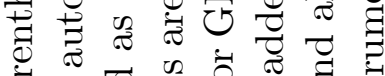

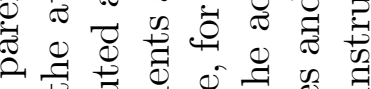
ॠ

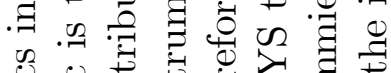

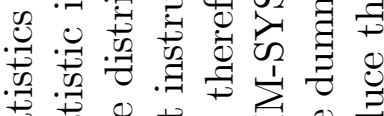

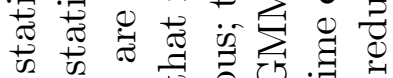
फे है.

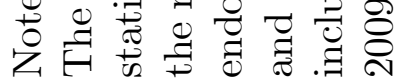




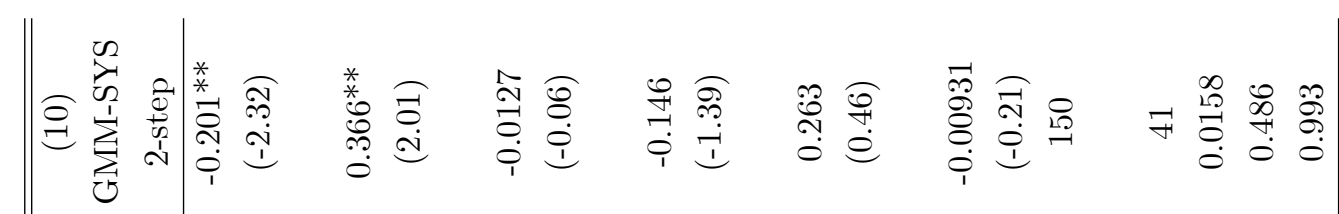

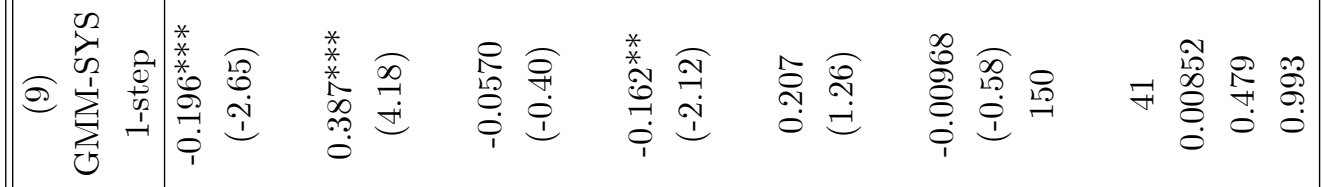

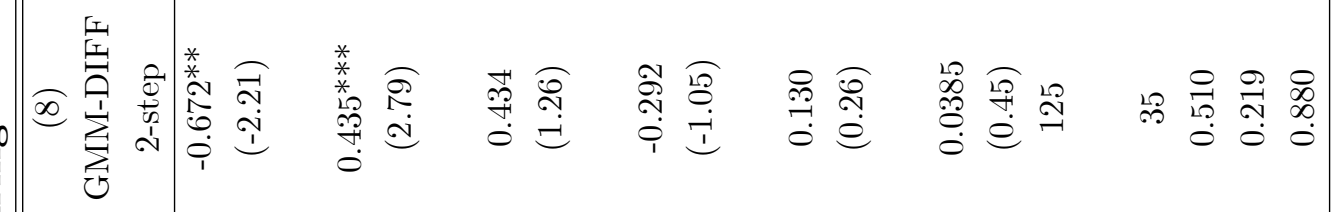

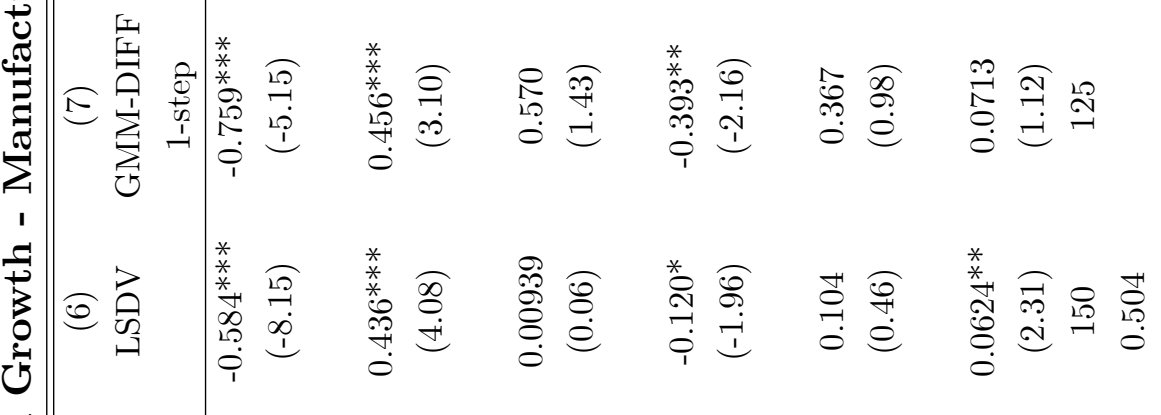

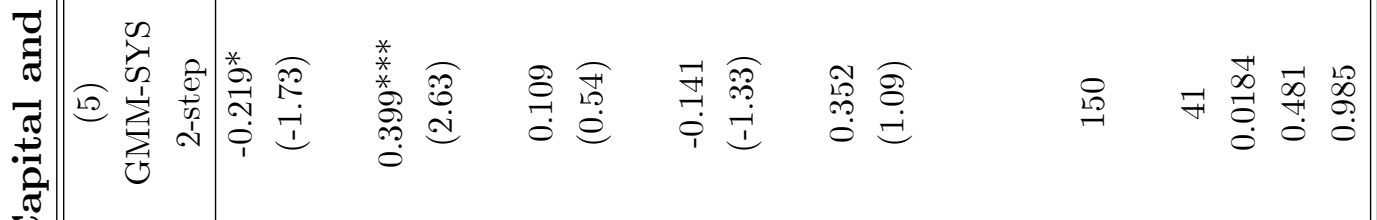

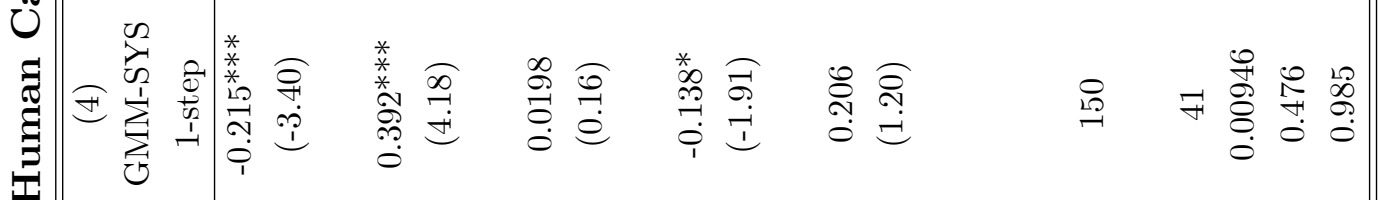

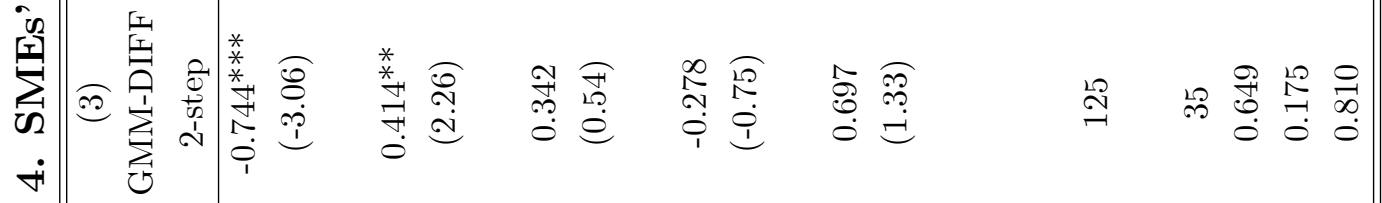

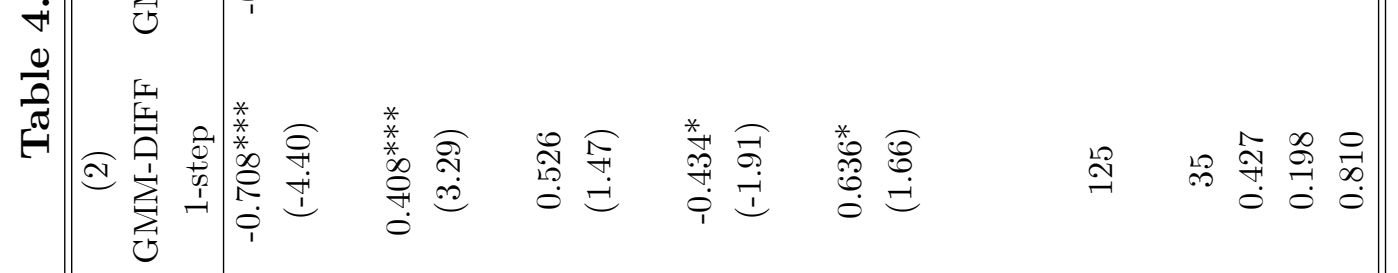

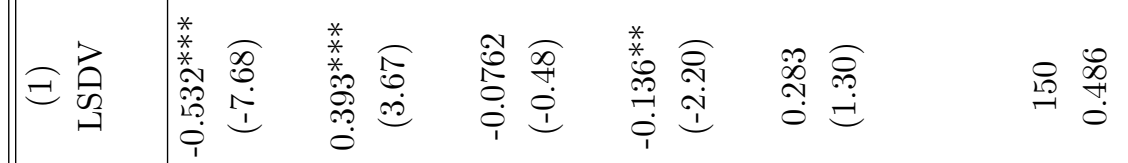

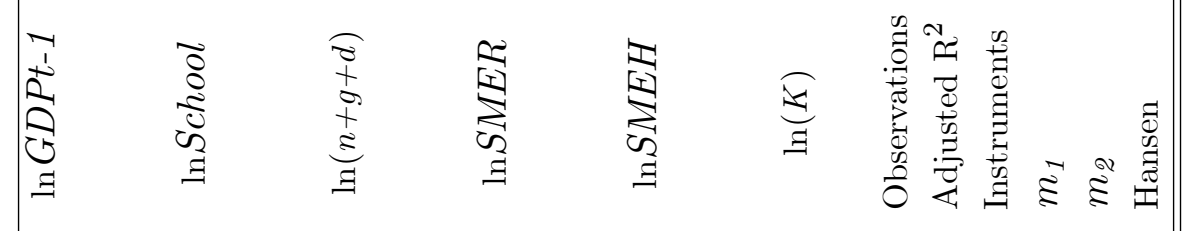

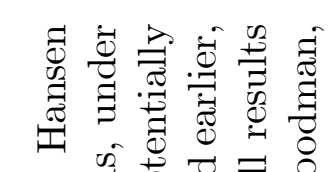

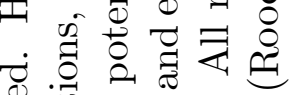

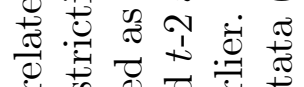

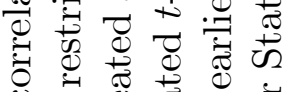
8.

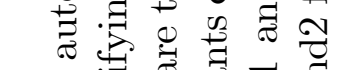

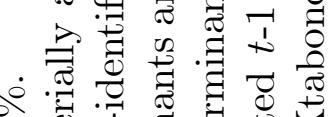

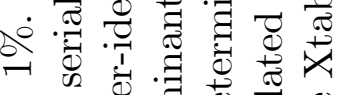

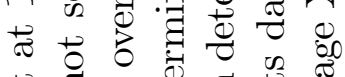

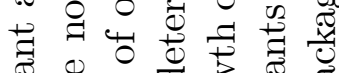

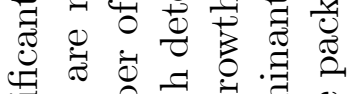

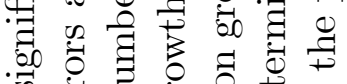

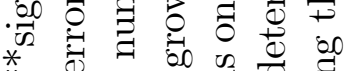
* ठ

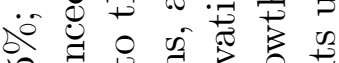
मी का

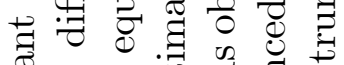

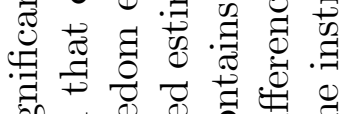

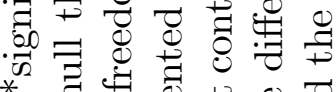
* S)

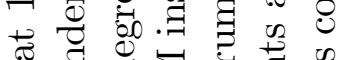

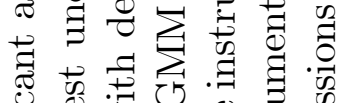

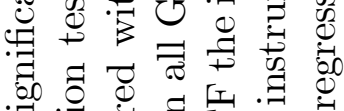
in * o w ․ㅡㄹ

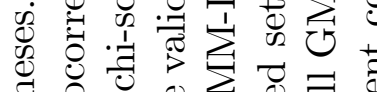

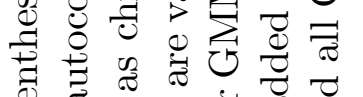

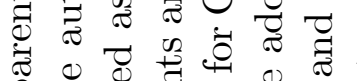
을

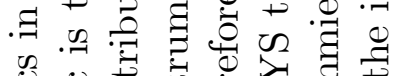

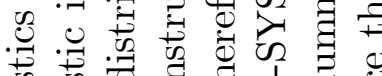

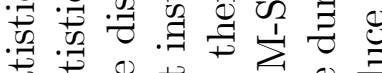

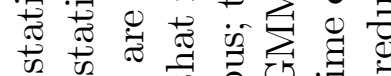

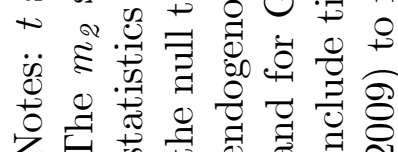




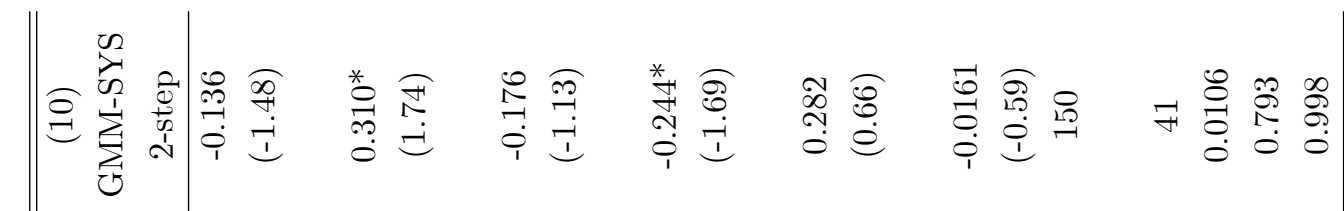

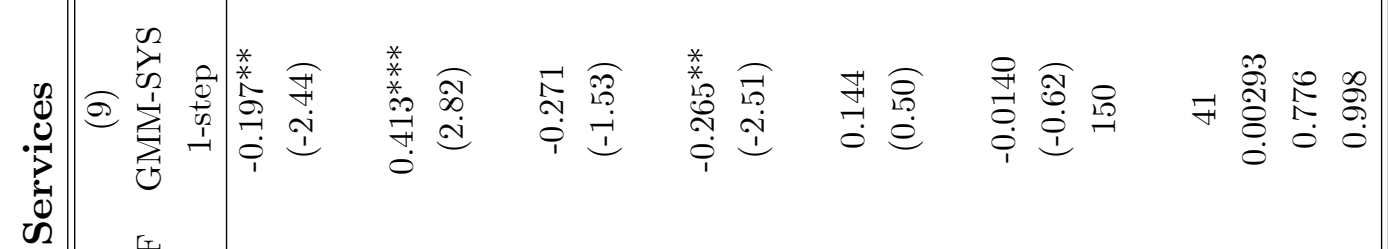

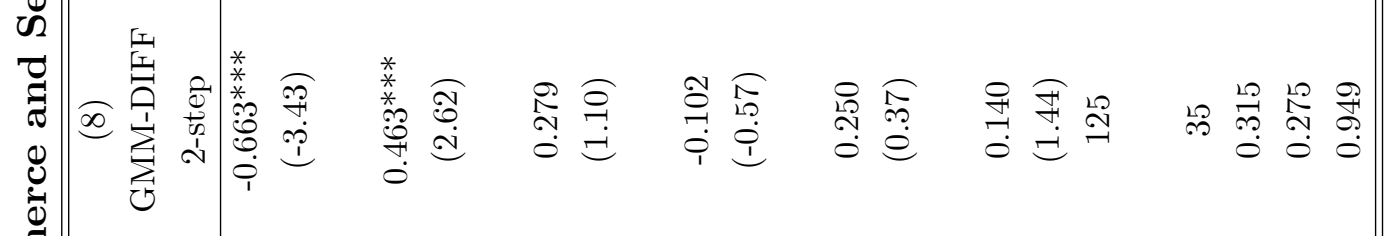

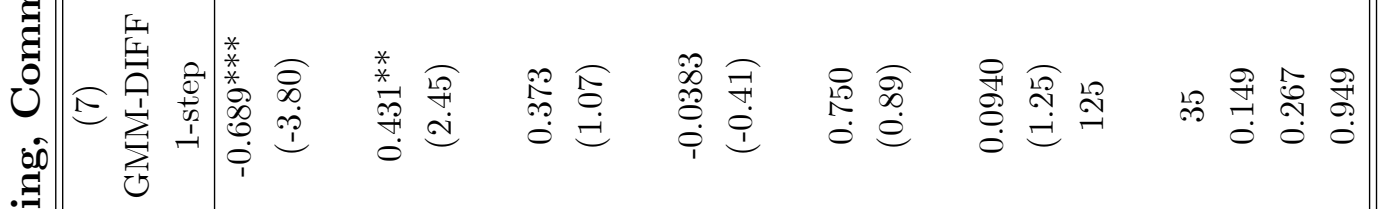

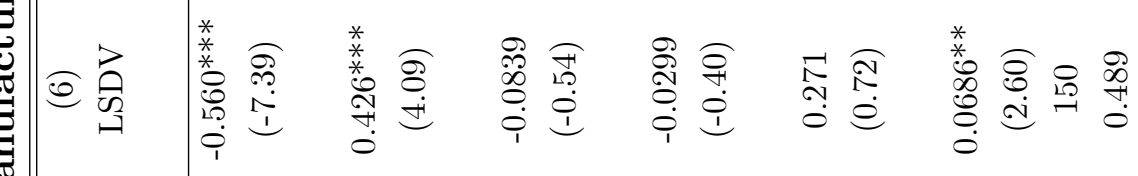

政

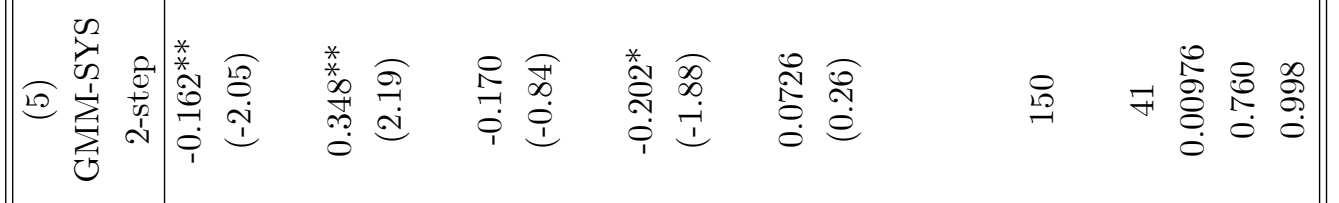

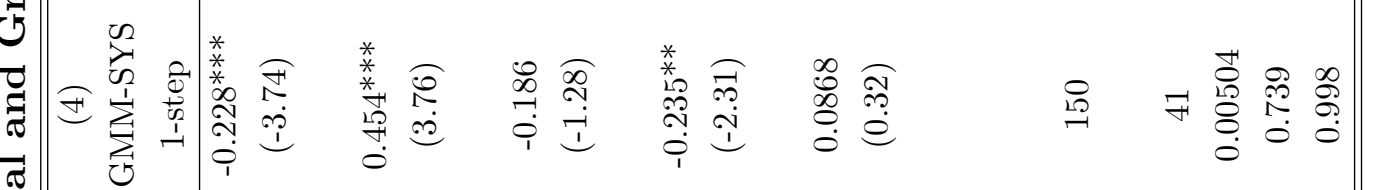

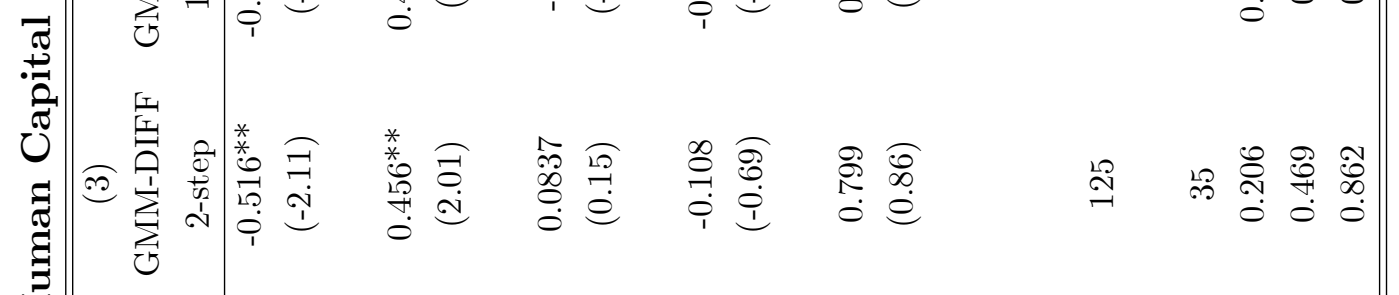

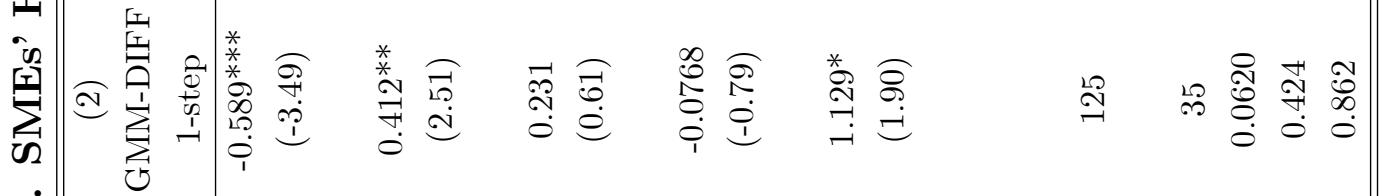

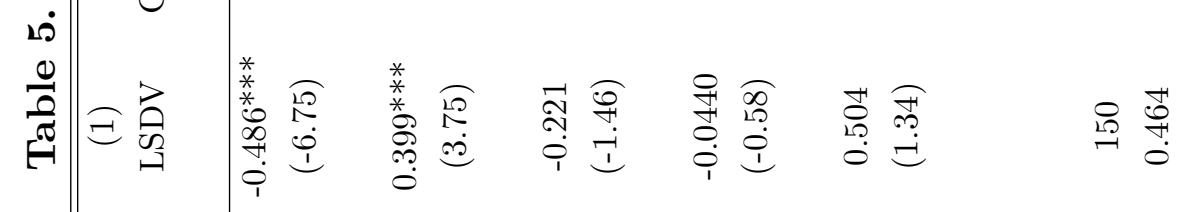

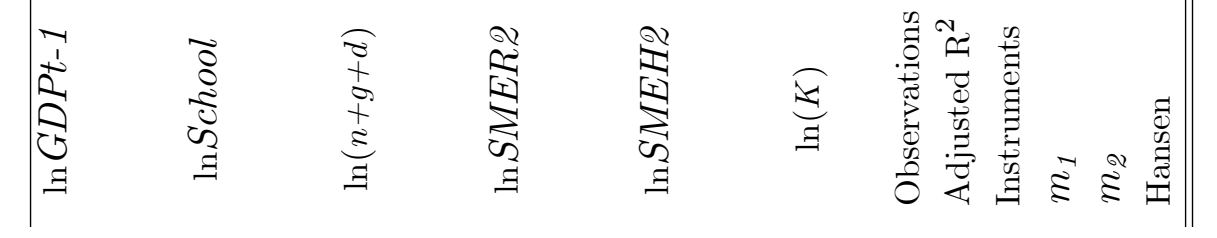

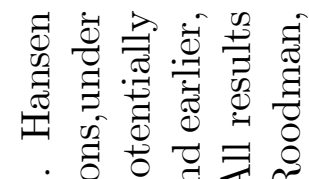

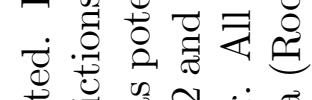

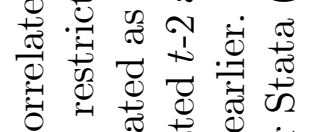
造

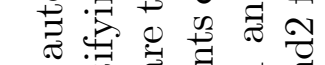

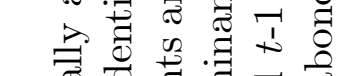
o

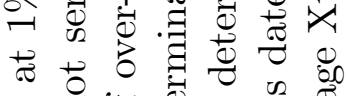

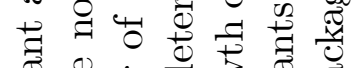

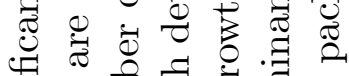
क्ञा . * के 0 50 च च * 엄 रें

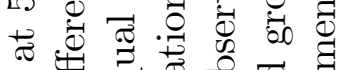

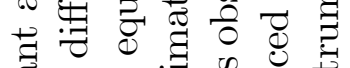

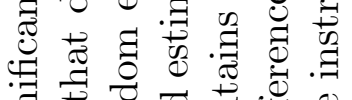

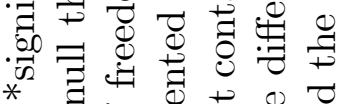

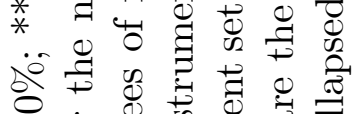
-

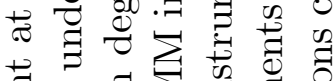

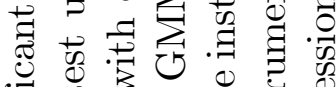
苛

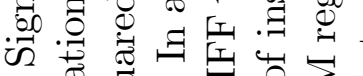

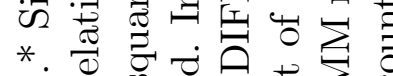

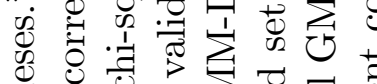

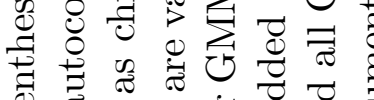
范

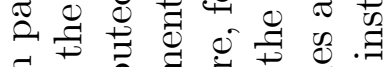
.

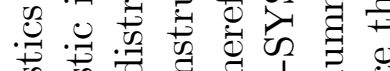

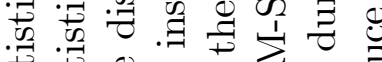

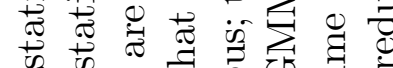
ஸे है.

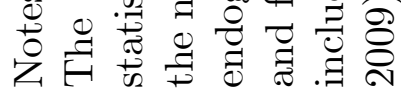




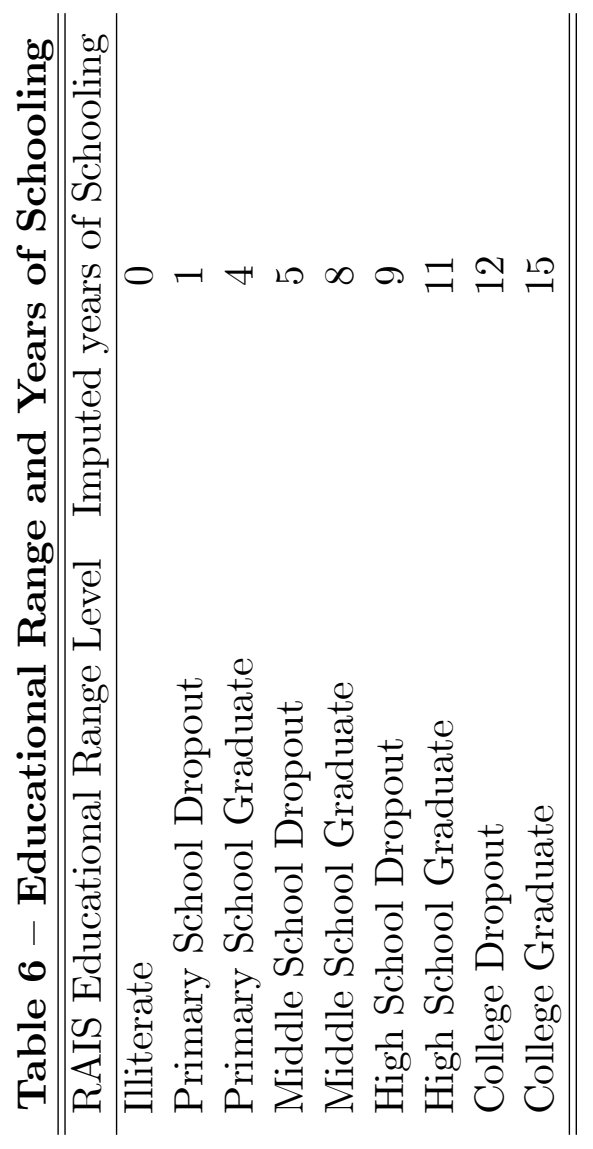

